\title{
Efficient 2,3-butanediol production from whey powder using metabolically engineered Klebsiella oxytoca
}

\author{
Wensi Meng ${ }^{1}$, Yongjia Zhang ${ }^{1}$, Menghao Cao ${ }^{1}$, Wen Zhang ${ }^{2}$, Chuanjuan Lü ${ }^{*}$, Chunyu Yang $^{1}$, Chao Gao ${ }^{1}$, \\ Ping $\mathrm{Xu}^{3}$ and Cuiqing $\mathrm{Ma}^{1 *} \mathbb{D}$
}

\begin{abstract}
Background: Whey is a major pollutant generated by the dairy industry. To decrease environmental pollution caused by the industrial release of whey, new prospects for its utilization need to be urgently explored. Here, we investigated the possibility of using whey powder to produce 2,3-butanediol (BDO), an important platform chemical.

Results: Klebsiella oxytoca strain PDL-0 was selected because of its ability to efficiently produce BDO from lactose, the major fermentable sugar in whey. After deleting genes $p o x, p t a, f r d A, I d h D$, and $p f B$ responding for the production of by-products acetate, succinate, lactate, and formate, a recombinant strain K. oxytoca PDL-K5 was constructed. Fedbatch fermentation using K. oxytoca PDL-K5 produced $74.9 \mathrm{~g} / \mathrm{L}$ BDO with a productivity of $2.27 \mathrm{~g} / \mathrm{L} / \mathrm{h}$ and a yield of $0.43 \mathrm{~g} / \mathrm{g}$ from lactose. In addition, when whey powder was used as the substrate, $65.5 \mathrm{~g} / \mathrm{L} \mathrm{BDO}$ was produced within $24 \mathrm{~h}$ with a productivity of $2.73 \mathrm{~g} / \mathrm{L} / \mathrm{h}$ and a yield of $0.44 \mathrm{~g} / \mathrm{g}$.
\end{abstract}

Conclusion: This study demonstrated the efficiency of $K$. oxytoca PDL-O for BDO production from whey. Due to its non-pathogenicity and efficient lactose utilization, K. oxytoca PDL-0 might also be used in the production of other important chemicals using whey as the substrate.

Keywords: Whey, Lactose, Klebsiella oxytoca PDL-0, 2,3-Butanediol, Metabolic engineering

\section{Background}

Whey, a liquid by-product generated during cheese production, contains most of the water-soluble components in milk $[1,2]$. Despite annual production of 145 million tons worldwide, only a little over one-half of the whey produced is utilized [3]. Whey is regarded as a serious pollutant because of its high biochemical oxygen demand (BOD, 30,000-50,000 $\mathrm{mg} / \mathrm{L}$ ) and chemical oxygen demand (COD, 60,000-80,000 mg/L) [3]. Economic disposal of whey has become a worldwide problem for the dairy industry. Lactose, a utilizable disaccharide for many

\footnotetext{
*Correspondence: chuanjuanlv@mail.sdu.edu.cn; macq@sdu.edu.cn 1 State Key Laboratory of Microbial Technology, Shandong University, Qingdao 266237, People's Republic of China

Full list of author information is available at the end of the article
}

microbial strains, is the major contributor to BOD and COD of whey $[4,5]$. Using the lactose in whey as a substrate for industrial microbial fermentation may transform a potential pollutant into a value-added product and this prospect deserves an intensive study.

2,3-Butanediol (BDO) is an important platform chemical that can be applied in many industrial fields [6-8]. Derivatives of $\mathrm{BDO}$ are estimated to have a potential global market of around 32 million tons per year. One common method for BDO synthesis is performed under harsh conditions $\left(160-220{ }^{\circ} \mathrm{C}, 50\right.$ bar) with a $\mathrm{C}_{4}$ hydrocarbon fraction of cracked gases as the substrate $[9,10]$. However, due to shortage of fossil fuels and increasing global environmental concerns, green production of BDO through microbial fermentation is desirable [1116]. Renewable resources such as rice waste biomass, 
sugarcane bagasse hydrolysate, and kenaf core biomass have been used in fermentative production of BDO [17-19].

Several BDO-producing microorganisms can use fermentable sugars, including glucose, xylose, fructose, and lactose as the sole carbon source for growth [20-23]. However, these strains exhibit unsatisfactory fermentative performance in $\mathrm{BDO}$ production when lactose is used as the carbon source. For example, Klebsiella oxytoca NRRL-B199 can use the mixture of glucose and galactose as substrate for growth and produce BDO as its main product. Nevertheless, BDO was present in a low concentration and the strain produced acetate as the major product in the fermentation broth with lactose [24, 25].

Production of BDO using whey as the substrate can enhance the economic feasibility of BDO fermentation and facilitate resource utilization of the pollutant whey. Therefore, it is critical to identify a suitable microbial strain with BDO production potential using lactose and whey. In this study, we cultured Klebsiella pneumonia ATCC 15380, Enterobacter cloacae SDM, Bacillus licheniformis DSM13, K. oxytoca PDL-0, and Escherichia coli BL21-pETRABC in fermentation broths with lactose as the carbon source. K. oxytoca PDL-0 exhibited the best performance in lactose utilization and BDO production. Next, byproduct-producing genes in $K$. oxytoca PDL-0, including pox, pta, frdA, ldhD, and $p f l B$, were knocked out to improve the efficiency of BDO production from lactose. Finally, high production of BDO from whey powder was achieved through fed-batch fermentation using the recombinant strain (Fig. 1).

\section{Results and discussion}

\section{Selection of $K$. oxytoca PDL-0 for BDO production}

\section{from lactose}

To select a strain for efficient BDO production from whey, we first assessed strains that can utilize lactose and produce BDO. K. pneumonia, E. cloacae, B. licheniformis, and $K$. oxytoca can produce BDO from glucose [16]. $E$. coli BL21-pETRABC carrying the BDO pathway gene cluster from $E$. cloacae can also efficiently bio-transform glucose into BDO [26]. In the present study, we first compared the ability of K. pneumonia ATCC 15380, E. cloacae SDM, B. licheniformis DSM13, K. oxytoca PDL-0, and $E$. coli BL21-pETRABC to produce BDO from lactose; results are shown in Fig. 2.

All five strains were cultured in M9 medium supplemented with $5 \mathrm{~g} / \mathrm{L}$ yeast extract and $\sim 40 \mathrm{~g} / \mathrm{L}$ lactose for $48 \mathrm{~h}$. B. licheniformis DSM13 is the only strain that cannot consume lactose. E. cloacae SDM and E. coli BL21pETRABC could grow well and utilize $\sim 30 \mathrm{~g} / \mathrm{L}$ lactose within $48 \mathrm{~h}$, but only accumulated about $2 \mathrm{~g} / \mathrm{L}$ BDO

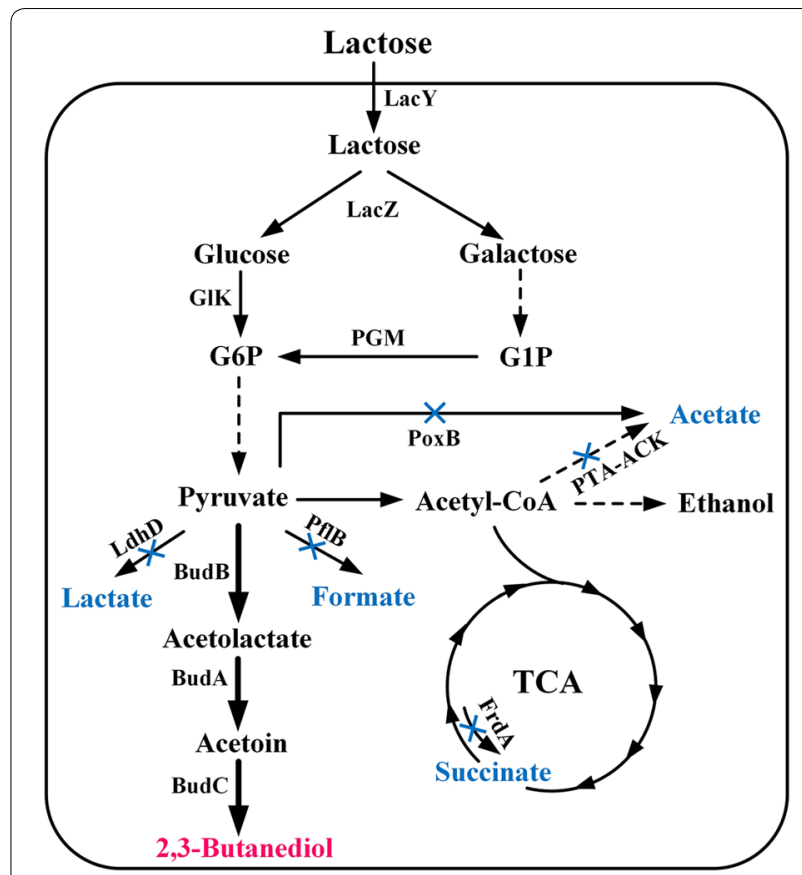

Fig. 1 Metabolic engineering strategies for efficient production of BDO from whey powder by K. oxytoca PDL-0. Solid lines represent one step reactions. Dashed lines represent multi-step reactions. Blue crosses indicated the blocked pathways in the metabolic engineered strain. The target product is shaded in red and the blocked byproducts are shaded in blue. GIP glucose-1-phosphate, G6P glucose-6-phosphate, LacY lactose permease, LacZ $\beta$-galactosidase,

GIK glucose kinase, PGM phosphoglucomutase, PoxB pyruvate oxidase, PTA phosphotransacetylase, ACK acetate kinase, FrdA catalytic subunit of fumarate reductase, $L d h D$ lactate dehydrogenase, PflB pyruvate formate-lyase, BudB a-acetolactate synthase, BudA a-acetolactate decarboxylase, BudC acetoin reductase

(Additional file 1: Fig. S1, Fig. 2a-c). K. pneumonia ATCC 15380 and $K$. oxytoca PDL-0 can completely consume $\sim 40 \mathrm{~g} / \mathrm{L}$ lactose within $36 \mathrm{~h}$ and $18 \mathrm{~h}$, and produce BDO from lactose with a yield of $0.21 \mathrm{~g} / \mathrm{g}$ and $0.30 \mathrm{~g} / \mathrm{g}$ lactose, respectively (Additional file 1: Fig. S1 and Fig. 2d). Considering the fact that $K$. oxytoca PDL-0 belongs to Risk Group 1 [15] and produces BDO from lactose with a higher yield than other strains, this strain was selected for further study in successive experiments.

\section{Inactivation of by-product pathways in $K$. oxytoca PDL-0} Klebsiella oxytoca PDL-0 produced BDO as its major fermentative product during lactose fermentation in a shaking flask culture. However, only $56 \%$ of theoretical yield ( 0.293 vs $0.526 \mathrm{~g} / \mathrm{g}$ ) was observed (Fig. 3). BDO is produced by a fermentative pathway known as the mixed acid-BDO pathway in $K$. oxytoca $[7,15]$. Acetate $(1.57 \mathrm{~g} / \mathrm{L})$, succinate $(1.14 \mathrm{~g} / \mathrm{L})$, lactate $(1.34 \mathrm{~g} / \mathrm{L})$, and 

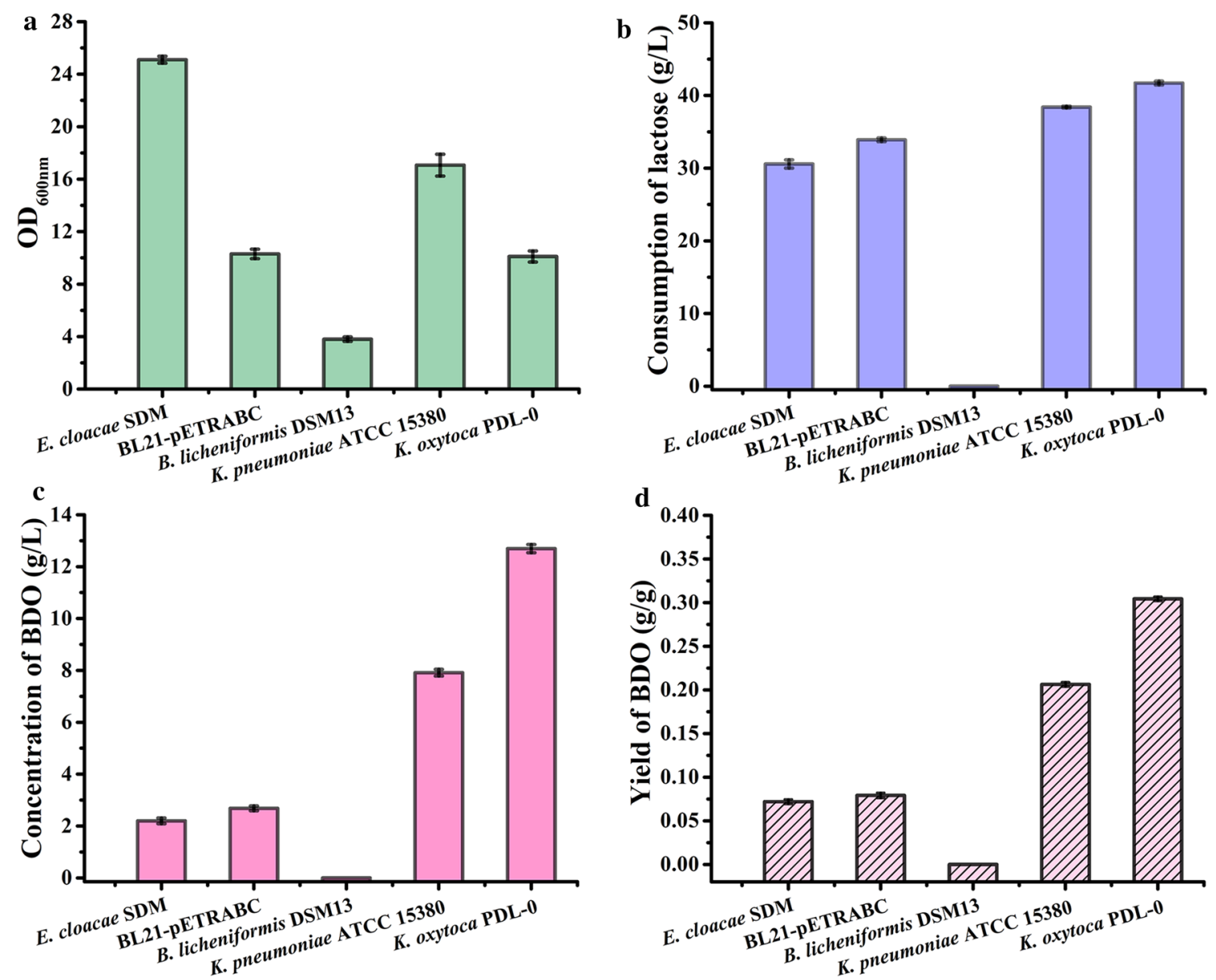

Fig. 2 Selection for stains that can produce BDO from lactose. Biomass (a), consumption of lactose (b), concentration (c) and yield (d) of BDO using lactose as the carbon source by E. cloacae SDM, E. coli BL21-pETRABC, B. licheniformis DSM13, K. pneumonia ATCC 15380, and K. oxytoca PDL-0 were assayed. The experiments were conducted in a 300-mL flask containing $50 \mathrm{~mL}$ of $\mathrm{M} 9$ minimal medium supplemented with $5 \mathrm{~g} / \mathrm{L}$ yeast extract and $40 \mathrm{~g} / \mathrm{L}$ lactose with shaking at $180 \mathrm{rpm}$ for $48 \mathrm{~h}$. The culture temperature for $B$. licheniformis DSM 13 was $50^{\circ} \mathrm{C}$ while for other strains were $37^{\circ} \mathrm{C}$. The data for K. oxytoca PDL-0 and K. pneumoniae ATCC 15380 were obtained at $18 \mathrm{~h}$ and $36 \mathrm{~h}$, respectively. The data for E. cloacae SDM, B. licheniformis DSM13 and E. coli BL21-pETRABC were obtained at $48 \mathrm{~h}$. Error bars indicate the standard deviations from three independent cultures

formate $(0.27 \mathrm{~g} / \mathrm{L})$ were also detected as by-products in the fermentation broth (Fig. 3).

In $K$. oxytoca PDL-0, the formation of acetate, succinate, lactate, and formate is catalyzed by pox and $p t a$, $f r d A, l d h D$, and $p f l B$, respectively [27]. To achieve higher $\mathrm{BDO}$ yield, these genes were successively deleted in strain K. oxytoca PDL-0 (Fig. 1). Effects of these gene deletions on growth, lactose consumption, by-product accumulation, and BDO production were studied in M9 medium supplemented with $5 \mathrm{~g} / \mathrm{L}$ yeast extract and $\sim 40 \mathrm{~g} / \mathrm{L}$ lactose. As shown in Fig. 3a, b, deletion of these by-product pathways in $K$. oxytoca PDL-0 had no effect on lactose consumption but did slightly increase growth. Accumulation of by-products, including acetate $(0.23 \mathrm{~g} / \mathrm{L})$, succinate $(0.70 \mathrm{~g} / \mathrm{L})$, lactate $(0.11 \mathrm{~g} / \mathrm{L})$, and formate $(0 \mathrm{~g} / \mathrm{L})$, was markedly decreased due to deletion of pox, pta, frdA, $l d h D$, and $p f l B$ (Fig. 3c). The final strain, K. oxytoca PDL$\mathrm{K} 5$, exhibited high concentration $(16.0 \mathrm{~g} / \mathrm{L})$ and yield $(0.36 \mathrm{~g} / \mathrm{g}$ lactose) of BDO (Fig. 3d, e) and low by-product generation (Fig. 3c).

\section{Performance of recombinant strain in 1-L batch fermentation}

The effects of inactivation of by-product pathways on BDO production were further studied through batch fermentation in a 1-L fermenter. The strains $K$. oxytoca PDL-0 and $K$. oxytoca PDL-K5 were cultured in a fermentation medium containing corn steep liquor powder as a nitrogen source and $\sim 40 \mathrm{~g} / \mathrm{L}$ lactose as carbon source. As shown in Fig. 4a, b, K. oxytoca PDL-0 consumed $42.75 \mathrm{~g} / \mathrm{L}$ lactose and produced $15.26 \mathrm{~g} / \mathrm{L}$ BDO 

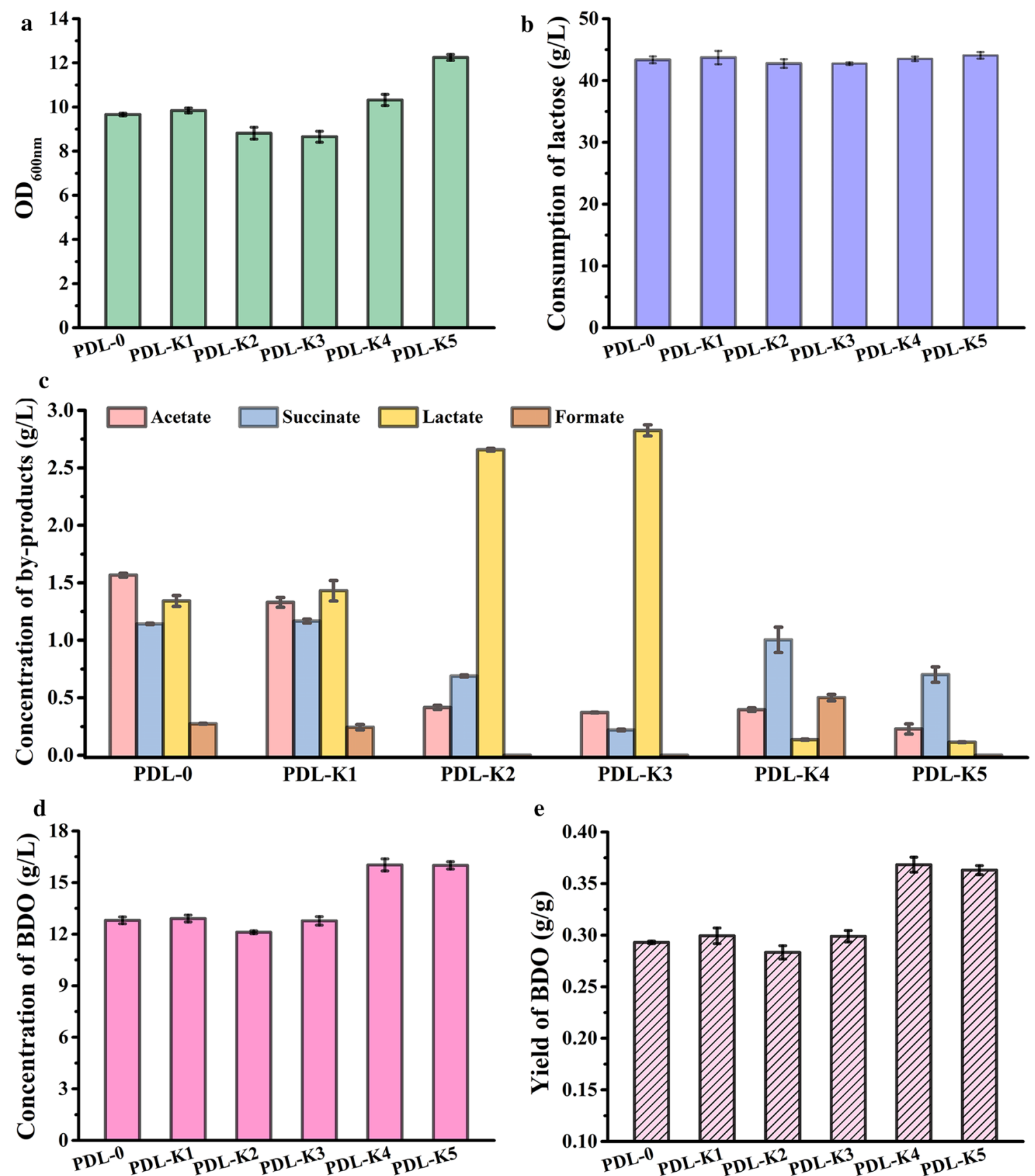

e

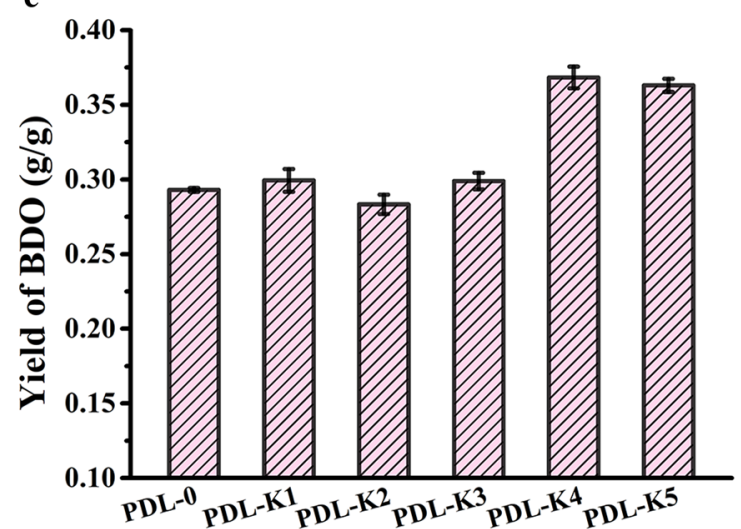

Fig. 3 Effects of by-product pathway genes knockout when using lactose as the carbon source. Biomass (a), consumption of lactose (b),

by-products $(\mathbf{c})$, concentration (d) and yield (e) of BDO by K. oxytoca PDL-0 and its derivatives were assayed. The experiments were conducted in a $300-\mathrm{mL}$ flask containing $50 \mathrm{~mL}$ of M9 minimal medium supplemented with $5 \mathrm{~g} / \mathrm{L}$ yeast extract and $40 \mathrm{~g} / \mathrm{L}$ lactose with shaking at $180 \mathrm{rpm}$ for $24 \mathrm{~h}$. The culture temperature was $37^{\circ} \mathrm{C}$. Error bars indicate the standard deviations from three independent cultures

with a yield of $0.36 \mathrm{~g} / \mathrm{g}$ at $12 \mathrm{~h}$, while $K$. oxytoca PDL$\mathrm{K} 5$ consumed $39.29 \mathrm{~g} / \mathrm{L}$ lactose and produced $17.65 \mathrm{~g} / \mathrm{L}$ BDO with a yield of $0.45 \mathrm{~g} / \mathrm{g}$. Thus, the recombinant strain $K$. oxytoca PDL-K5 demonstrates advantages over wild type in both concentration and yield of BDO.

\section{Utilization of lactose for BDO production in fed-batch} fermentation

To achieve higher product concentration, we performed fed-batch fermentation using strain K. oxytoca PDL-K5 with initial lactose concentration of $\sim 100 \mathrm{~g} / \mathrm{L}$. Fermentation medium containing corn steep liquor was used in 


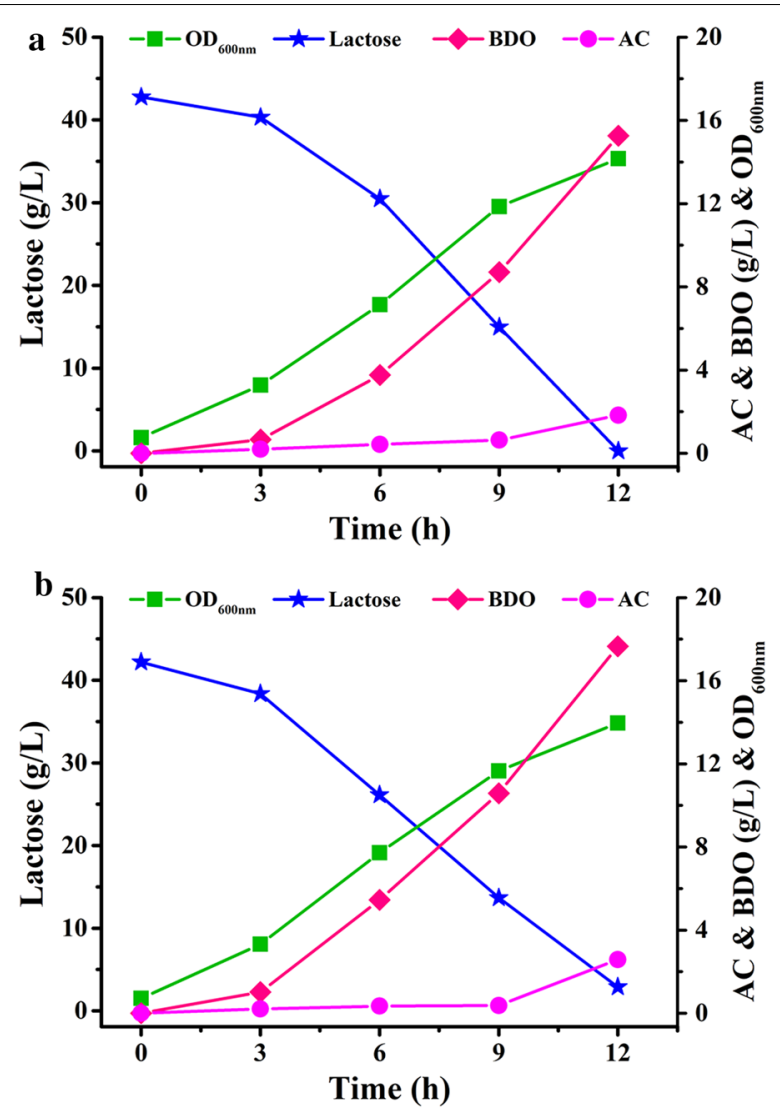

Fig. 4 Batch fermentation using lactose as carbon source. Biomass, consumption of lactose, concentration of BDO and acetoin (AC) by $K$. oxytoca PDL-0 (a) and K. oxytoca PDL-K5 (b) were assayed. The experiments were conducted in a 1-L fermenter containing $800 \mathrm{~mL}$ of medium with an initial lactose concentration of $40 \mathrm{~g} / \mathrm{L}$ approximately

a 7.5-L fermenter. As shown in Fig. 5a, 173.2 g/L lactose was consumed and $74.9 \mathrm{~g} / \mathrm{L}$ BDO was produced within $33 \mathrm{~h}$. The productivity was $2.27 \mathrm{~g} / \mathrm{L} / \mathrm{h}$ and the yield was $0.43 \mathrm{~g} / \mathrm{g}$ lactose. The final concentration of the major byproduct succinate was $0.82 \mathrm{~g} / \mathrm{L}$ and there was no formate production throughout the fermentation process (Additional file 1: Fig. S2a).

\section{Utilization of whey powder for BDO production in fed-batch fermentation}

Fed-batch fermentation using $K$. oxytoca PDL-K5 with whey powder as the carbon source was also conducted. After $24 \mathrm{~h}$ of fermentation, $65.5 \mathrm{~g} / \mathrm{L}$ BDO was obtained from $148.3 \mathrm{~g} / \mathrm{L}$ lactose (Fig. $5 \mathrm{~b}$ ). The productivity and yield of BDO were $2.73 \mathrm{~g} / \mathrm{L} / \mathrm{h}$ and $0.44 \mathrm{~g} / \mathrm{g}$, respectively. The major by-products in the final fermentation broth were acetate and lactate, which were found at concentrations of $3.24 \mathrm{~g} / \mathrm{L}$ and $0.38 \mathrm{~g} / \mathrm{L}$, respectively (Additional file 1: Fig. S2b). During fermentation, agitation and airflow were set at $400 \mathrm{rpm}$ and $1 \mathrm{vvm}$, respectively,
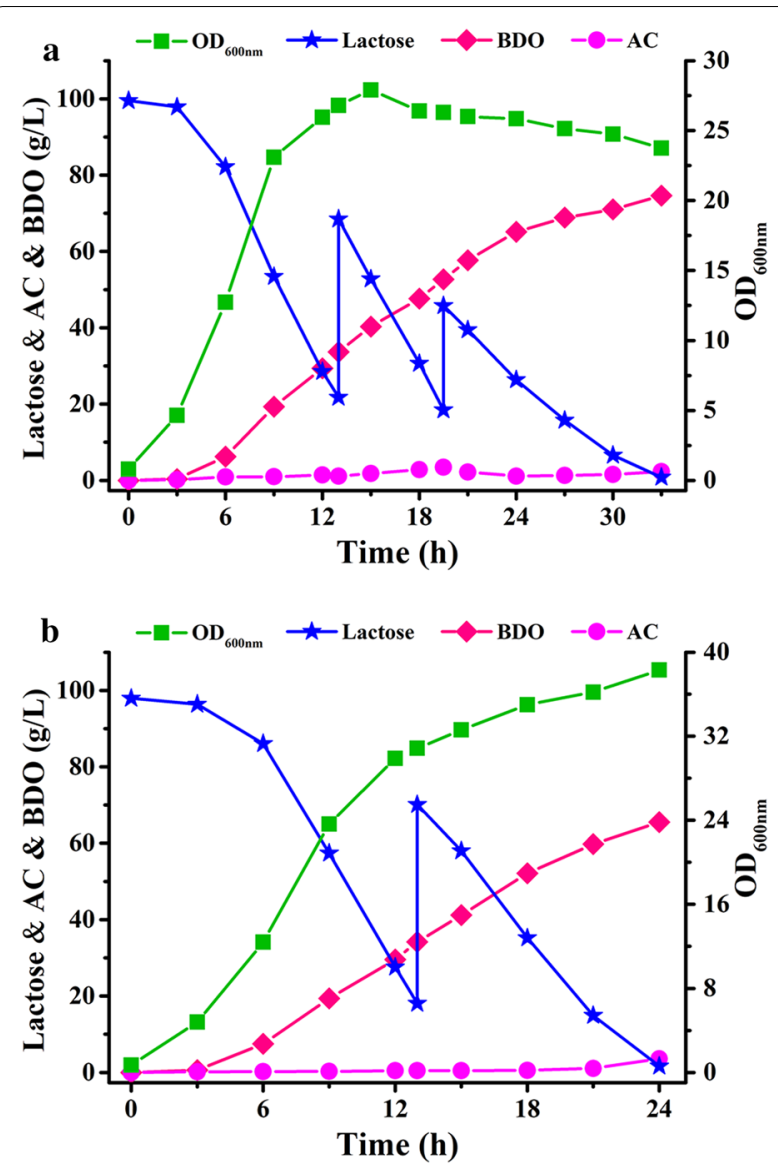

Fig. 5 Fed-batch fermentation using lactose (a) and whey powder (b) as the carbon source. Biomass, consumption of lactose, concentration of BDO and acetoin (AC) by K. oxytoca PDL-K5 were assayed. The experiments were conducted in a 7.5-L fermenter containing $5 \mathrm{~L}$ of medium with an initial lactose concentration of $100 \mathrm{~g} / \mathrm{L}$ approximately

and dissolved oxygen was uncontrolled. Acetoin started to accumulate at the end of fermentation and feeding more whey powder into the fermentation system did not increase $\mathrm{BDO}$ production. Dissolved oxygen has a profound impact on the distribution of BDO and its dehydrogenation product, acetoin. Since BDO biosynthesis occurs under microaerobic conditions [28, 29], fine-tuning the dissolved oxygen through an automatic control system might provide the optimal microaerobic condition to further increase BDO production.

Several microbial strains have been screened to produce BDO from whey or lactose. However, as shown in Table 1, the final concentration and yield of BDO produced by wildtype isolates were relatively low. For example, Vishwakarma tried to use strain $K$. oxytoca NRRL-13-199 for BDO production from whey. After the addition of $50 \mathrm{mM}$ acetate, $8.4 \mathrm{~g} / \mathrm{L} \mathrm{BDO}$ was acquired with a yield of $0.365 \mathrm{~g} / \mathrm{g}$ lactose [30]. Barrett et al. studied 
Table 1 Comparison of BDO production using whey/lactose as substrate by different microorganisms

\begin{tabular}{|c|c|c|c|c|c|c|}
\hline Strain & Substrate & Method & $\begin{array}{l}\text { Concentration } \\
\text { (g/L) }\end{array}$ & Yield (g/g) & $\begin{array}{l}\text { Productivity } \\
\text { (g/L/h) }\end{array}$ & References \\
\hline Bacillus polymyxa ATCC 1232 & Cheese whey & Wild-type & 5.5 & 0.25 & 0.03 & {$[22]$} \\
\hline K. pneumoniae NCIB 8017 & Rennet whey permeate & Wild-type & 7.5 & 0.46 & 0.08 & {$[42]$} \\
\hline K. oxytoca NRRL-13-199 & Whey & $\begin{array}{l}\text { Wild-type, adding } 50 \text { mM } \\
\text { acetate }\end{array}$ & 8.4 & 0.365 & - & {$[30]$} \\
\hline Enterobacter aerogenes 3889 & Whey & $\begin{array}{l}\text { Wild-type, using neutralized } \\
\text { acid whey with } 50 \mathrm{mM} \\
\text { acetate }\end{array}$ & 15.1 & - & 0.24 & {$[23]$} \\
\hline K. pneumoniae ATCC 13882 & Whey & $\begin{array}{l}\text { Wild-type, using unsterilized } \\
\text { acid whey and adjusting } \\
\text { pH to } 6.5\end{array}$ & 19.3 & - & 0.32 & {$[23]$} \\
\hline Lactococcus lactis mL001 & $\begin{array}{l}\text { Residual whey permeate } \\
\text { (lactose) }\end{array}$ & $\begin{array}{l}\text { Deletion of Idh, IdhB, } \\
\text { IdhX, pta, adhE, butBA, } \\
\text { overexpression of bdh and } \\
\text { lactose utilizing pathway in } \\
\text { L. lactis MG1363 }\end{array}$ & 51 & 0.47 & 1.46 & {$[32]$} \\
\hline K. oxytoca PDL-K5 & Whey powder & $\begin{array}{l}\text { Deletion of pox, pta, frdA, } \\
\text { IdhD, pflB in K. oxytoca } \\
\text { PDL-0 }\end{array}$ & 65.5 & 0.44 & 2.73 & This study \\
\hline K. pneumoniae KG1 & Lactose & Wild-type & 4.38 & 0.33 & 0.365 & {$[21]$} \\
\hline $\begin{array}{l}\text { K. oxytoca NRRL-B199 with } \\
\text { nonviable cells of Kluyvero- } \\
\text { myces lactis CBS } 683\end{array}$ & Lactose & $\begin{array}{l}\text { Wild-type, co-immobili- } \\
\text { zation by adhesion of } \\
\beta \text {-galactosidase in nonvi- } \\
\text { able cells of K. lactis with K. } \\
\text { oxytoca }\end{array}$ & 14.3 & 0.29 & 0.80 & {$[25]$} \\
\hline K. oxytoca ATCC 8724 & Lactose & Wild-type & 32.49 & 0.207 & 0.861 & {$[31]$} \\
\hline K. oxytoca PDL-K5 & Lactose & $\begin{array}{l}\text { Deletion of pox, pta, frdA, } \\
\text { IdhD, pflB in K. oxytoca } \\
\text { PDL-0 }\end{array}$ & 74.9 & 0.43 & 2.27 & This study \\
\hline
\end{tabular}

production of BDO from whey by $K$. pneumoniae ATCC 13882 [23]. After $60 \mathrm{~h}$ of fermentation, $19.3 \mathrm{~g} / \mathrm{L}$ BDO was produced from whey with a productivity of $0.32 \mathrm{~g} / \mathrm{L} / \mathrm{h}$. Ramachandran et al. obtained a concentration of $32.49 \mathrm{~g} / \mathrm{L}$ BDO from lactose by using K. oxytoca ATCC 8724; however, the yield $(0.207 \mathrm{~g} / \mathrm{g}$ lactose $)$ and productivity $(0.861 \mathrm{~g} / \mathrm{L} / \mathrm{h})$ of BDO were still unsatisfactory [31]. In a previous work, Lactococcus lactis MG1363 was metabolically engineered to produce $\mathrm{BDO}$ from residual whey permeate, and a final titer of $51 \mathrm{~g} / \mathrm{L}$ BDO was acquired [32]. Exogenous antibiotics were needed for the maintenance of two plasmids, PJM001 and pLP712, which carry the genes needed for BDO production and metabolism of lactose, respectively. To make bio-based BDO production from whey more economically efficient and environment-friendly, BDO production without antibiotic addition to the fermentation system for the maintenance of plasmids should be initiated. In this work, $K$. oxytoca PDL-0 was metabolically engineered to efficiently produce BDO from lactose in whey powder through deleting $p o x, p t a, f r d A, l d h D$, and $p f l B$. Using whey powder as the carbon source, the recombinant strain $K$. oxytoca PDL$\mathrm{K} 5$ can produce $65.5 \mathrm{~g} / \mathrm{L}$ BDO (Table 1). Compared with other strains used for BDO production from whey, the engineered strain has significant production advantages, such as high product concentration $(65.5 \mathrm{~g} / \mathrm{L})$, high productivity $(2.73 \mathrm{~g} / \mathrm{L} / \mathrm{h})$, and lack of a need for unnecessary exogenous antibiotics.

Recently, lactose or whey have been used to produce various biochemicals, e.g., ethanol [33], butanol [34], lactic acid [35], citric acid [36], poly(3-hydroxybutyrate) (PHB) [37], and gluconic acid [38], through endogenous or exogenous biosynthetic pathways. However, because of the low utilization efficiency of lactose in these chassis cells, it is difficult to produce the target chemicals with high productivity and high yield $[34,36]$. Ahn et al. constructed a fermentation strategy with a cell-recycle membrane system for the production of PHB from whey [37]. A high consumption rate of lactose $(7.67 \mathrm{~g} / \mathrm{L} / \mathrm{h})$ was acquired using this complicated fermentation strategy. The engineered strain $K$. oxytoca PDL-K5 in this study had the ability to efficiently transform lactose in whey powder into BDO with relatively high yield $(0.44 \mathrm{~g} / \mathrm{g})$ and high consumption rate of lactose $(6.18 \mathrm{~g} / \mathrm{L} / \mathrm{h})$. This work provides a suitable method for BDO production as well as whey utilization (Fig. 6). Considering its excellent 


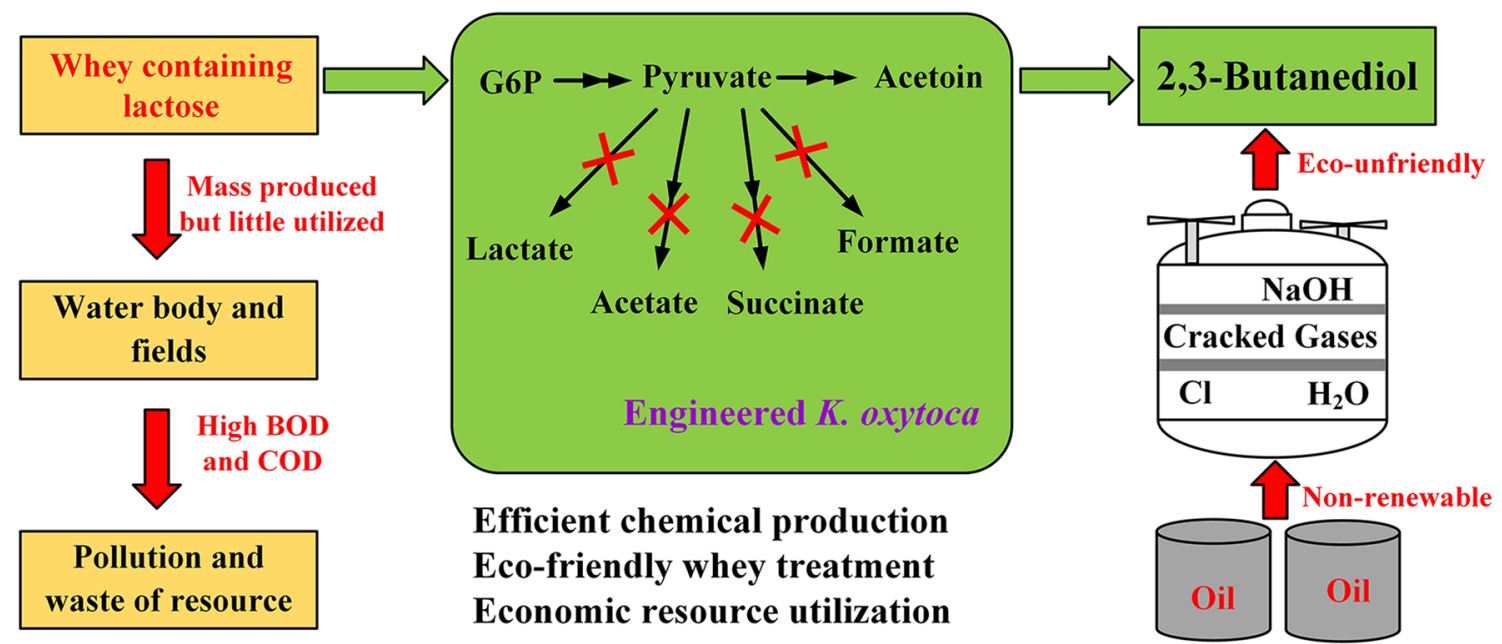

Fig. 6 Scheme of BDO production from whey using metabolic engineered K. oxytoca. G6P glucose-6-phosphate

characteristics of non-pathogenicity (Risk Group 1) and efficient lactose utilization, $K$. oxytoca PDL-0 may be a promising chassis for production of various chemicals from whey through metabolic engineering. For example, acetoin, the oxidized precursor of $\mathrm{BDO}$, might be produced through increasing dissolved oxygen levels and deleting 2,3-butanediol dehydrogenases responsible for BDO production from acetoin [39].

\section{Conclusions}

In this study, the ability of $K$. oxytoca PDL- 0 to metabolize lactose and produce BDO was identified. Then, byproduct pathways encoding genes in K. oxytoca PDL-0 were knocked out to improve the yield of BDO. The engineered strain $K$. oxytoca PDL-K5 was able to utilize whey powder as the substrate for high production of BDO. The fermentative process developed here is a promising alternative method for both biotechnological production of $\mathrm{BDO}$ and whey utilization. In addition, other important chemicals may also be produced from whey using metabolically engineered $K$. oxytoca PDL- 0 , which has the characteristics of efficient lactose utilization.

\section{Methods}

\section{Enzymes and chemicals}

FastPfu DNA polymerase was purchased from TransGen Biotech (Beijing, China) and T4 DNA ligase from Thermo Scientific (Lithuania). Restriction enzymes were purchased from TaKaRa Bio Inc. (Dalian, China). Polymerase chain reaction (PCR) primers were provided by Tsingke Biology Co., Ltd (QingDao, China). Racemic acetoin and BDO was purchased from Apple Flavor \& Fragrance Group (Shanghai, China) and ACROS (The
Kingdom of Belgium), respectively. Whey powder with a lactose content of $77 \%$ was purchased from KuoQuan Biotech (Shandong, China). All other chemicals were of analytical grade and commercially available.

\section{Bacterial strains, plasmids and culture medium}

The strains and plasmids used in this study are listed in Table 2. All engineered strains used in this work are based on $K$. oxytoca PDL-0 and its derivatives. E. coli S17-1 was used to hold and amplify plasmids as well as for conjugation with $K$. oxytoca. The plasmid $\mathrm{pKR} 6 \mathrm{~K}_{\mathrm{Cm}}$ was used for gene knockout in K. oxytoca [27].

Luria-Bertani (LB) medium was used for the cultivation of all the strains used. The M9 minimal medium [40] supplemented with $5 \mathrm{~g} / \mathrm{L}$ yeast extract and $40 \mathrm{~g} / \mathrm{L}$ lactose was used in shake flasks experiments for selection of the efficient BDO producing strain. The selection medium for single exchange strains of $K$. oxytoca was M9 minimal medium supplemented with $20 \mathrm{~g} / \mathrm{L}$ sodium citrate and $40 \mu \mathrm{g} / \mathrm{mL}$ chloramphenicol. The selection medium for double exchange strains of $K$. oxytoca was solid LB medium supplemented with $15 \%$ sucrose.

\section{Knockout the genes of $K$. oxytoca PDL-0}

The primers used for knockout of byproduct-producing genes in $K$. oxytoca PDL-0 are listed in Additional file 1: Table S1. Vector isolation, restriction enzyme digestion, agarose gel electrophoresis, and other DNA manipulations were carried out using standard protocols [41]. Knockout mutants of $K$. oxytoca PDL-0 were generated via allele exchange using the suicide plasmid $\mathrm{pKR} 6 \mathrm{~K}_{\mathrm{Cm}}$ [27]. The left and right flanking sequences were amplified from $K$. oxytoca PDL-0 and then ligated through 
Table 2 Strains and plasmids used in this study

\begin{tabular}{|c|c|c|}
\hline Strain or plasmid & Characteristic(s) & References or sources \\
\hline \multicolumn{3}{|l|}{ Strain } \\
\hline Escherichia coli S17-1 & rec $A$, pro, thi, conjugative strain able to host $\lambda$-pir-dependent plasmids & [43] \\
\hline Enterobacter cloacae SDM & Wild-type & [12] \\
\hline E. coli BL21-pETRABC & E. coli BL21 (DE3) harboring pET-RABC & [26] \\
\hline Klebsiella pneumonia ATCC 15380 & Wild-type & ATCC \\
\hline Bacillus licheniformis DSM13 & Wild-type & DSMZ \\
\hline Klebsiella oxytoca PDL-0 & Wild-type & ССТCC M 2016184 \\
\hline K. oxytoca PDL-K1 & K. oxytoca PDL-0 with deletion of pox & This study \\
\hline K. oxytoca PDL-K2 & K. oxytoca PDL-0 with deletion of pox and pta & This study \\
\hline K. oxytoca PDL-K3 & K. oxytoca PDL-0 with deletion of pox, pta, and frdA & This study \\
\hline K. oxytoca PDL-K4 & K. oxytoca PDL-0 with deletion of pox, pta, frdA, and IdhD & This study \\
\hline K. oxytoca PDL-K5 & K. oxytoca PDL-0 with deletion of pox, pta, frdA, IdhD, and pflB & This study \\
\hline \multicolumn{3}{|l|}{ Plasmid } \\
\hline $\mathrm{pKR} \mathrm{K}_{\mathrm{Cm}}$ & $\begin{array}{l}\mathrm{Cm}^{r} \text {, gene replacement vector derived from plasmid pK } 18 \text { mobsacB, R6K origin, } \\
\mathrm{Mob}^{+} \text {sacB, and the } \mathrm{Km}^{r} \text { resistance was replaced by } \mathrm{Cm}^{r}\end{array}$ & [27] \\
\hline $\mathrm{pKD} \triangle \mathrm{pox}$ & pKR6K $_{\mathrm{Cm}}$ derivative, carries a 580 bp deletion of pox & This study \\
\hline $\mathrm{pKD} \triangle \mathrm{pta}$ & pKR6K $_{\mathrm{cm}}$ derivative, carries a $1152 \mathrm{bp}$ deletion of pta & This study \\
\hline $\mathrm{pKD} \triangle \mathrm{frdA}$ & pKR6K $_{C m}$ derivative, carries a 720 bp deletion of frdA & This study \\
\hline $\mathrm{pKD} \Delta / \mathrm{dhD}$ & pKR6K $_{\mathrm{cm}}$ derivative, carries a $386 \mathrm{bp}$ deletion of IdhD & This study \\
\hline $\mathrm{pKD} \triangle \mathrm{pflB}$ & pKR6K $_{C m}$ derivative, carries a 1150 bp deletion of pflB & This study \\
\hline
\end{tabular}

PCR to get $\Delta p o x$ fragment using primer pairs P $\Delta p o x . \mathrm{f}$ (EcoRI)/P $\Delta$ pox.r (overlap) and P $\Delta p o x . f$ (overlap)/P $\Delta p o x . r$ (BamHI), respectively. The gel-purified $\Delta p o x$ fragments were ligated to the $\mathrm{pKR} 6 \mathrm{~K}_{\mathrm{Cm}}$ digested with EcoRI and BamHI. The resulting plasmid was designated pKD $\Delta p o x$ and introduced into $E$. coli S17-1. Then, a three-step deletion procedure was applied to select the $\Delta p o x$ mutant after conjugating the pKD $\Delta p o x$ in $K$. oxytoca PDL-0 as described previously [27]. The $p t a, f r d A, l d h D$, and $p f l B$ mutants of strain $K$. oxytoca PDL- 0 were generated by using the same procedure and primers listed in Additional file 1: Table S1.

\section{Batch and fed-batch fermentations}

Batch fermentations were conducted in a 1-L bioreactor (Multifors 2, Infors AG, Switzerland) with $0.8 \mathrm{~L}$ of medium. The seed culture was inoculated $(10 \%, \mathrm{v} / \mathrm{v})$ into the fermentation medium containing $8.27 \mathrm{~g} / \mathrm{L}$ corn steep liquor powder (CSLP); $4.91 \mathrm{~g} / \mathrm{L}\left(\mathrm{NH}_{4}\right)_{2} \mathrm{HPO}_{4} ; 3 \mathrm{~g} / \mathrm{L}$ sodium acetate; $0.4 \mathrm{~g} / \mathrm{L} \mathrm{KCl} ; 0.1 \mathrm{~g} / \mathrm{L} \mathrm{MgSO}_{4} ; 0.02 \mathrm{~g} / \mathrm{L}$ $\mathrm{FeSO}_{4} \cdot 7 \mathrm{H}_{2} \mathrm{O} ; 0.01 \mathrm{~g} / \mathrm{L} \mathrm{MnSO}_{4} \cdot 7 \mathrm{H}_{2} \mathrm{O}$ and $40 \mathrm{~g} / \mathrm{L}$ lactose. The cultivation was carried out at $37{ }^{\circ} \mathrm{C}$, stirring at $400 \mathrm{rpm}$, airflow at $1.0 \mathrm{vvm}$ and initial $\mathrm{pH}$ of 7.0. When $\mathrm{pH}$ dropped to 6.0, it was maintained at this level by automatic addition of $4 \mathrm{M} \mathrm{H}_{3} \mathrm{PO}_{4}$ or $5 \mathrm{M} \mathrm{NaOH}$. Fedbatch fermentation was carried out in a 7.5-L fermenter (BioFlo 310, NBS, USA) containing $5 \mathrm{~L}$ of medium and the cultivation condition was the same as 1 - $\mathrm{L}$ fermenter except that the initial concentration of lactose was about $100 \mathrm{~g} / \mathrm{L}$. Alternatively, $130 \mathrm{~g} / \mathrm{L}$ whey powder was fed into the fermentation broth to make the initial concentration of lactose at about $100 \mathrm{~g} / \mathrm{L}$. Solid lactose or whey powder was fed in the fermenter when residual lactose concentration was reduced to about $20 \mathrm{~g} / \mathrm{L}$.

\section{Analytical methods}

The optical density (OD) was measured at $600 \mathrm{~nm}$ using a spectrophotometer (V5100H, Shanghai Metash Instruments Co., Ltd, China) after an appropriate dilution. The concentrations of lactose and other by-products were detected by high performance liquid chromatography (HPLC) in an Agilent 1100 series, equipped with a Aminex HPX-87H column $(300 \times 7.8 \mathrm{~mm}$; Bio-Rad, USA) and a refractive index detector [40]. The mobile phase was $10 \mathrm{mM} \mathrm{H}_{2} \mathrm{SO}_{4}$ at a flow rate of $0.4 \mathrm{~mL} / \mathrm{min}$ at $55^{\circ} \mathrm{C}$. The concentrations of acetoin and BDO were analyzed by gas chromatography (GC) (Shimadzu, GC2014c) using a capillary GC column (AT. SE-54, inside diameter, $0.32 \mathrm{~mm}$; length, $30 \mathrm{~m}$, Chromatographic Technology Center, Lanzhou Institute of Chemical Physics, China). Prior to GC analysis, the sample was extracted by ethyl acetate with isoamyl alcohol as the internal standard. Nitrogen was used as the carrier gas for GC analysis. The temperature of both the injector and the detector was $280^{\circ} \mathrm{C}$, the column oven was maintained at $80^{\circ} \mathrm{C}$ for 
3 min. Statistical analysis of the results was conducted using Origin 9.0 (OriginLab, USA). Unless otherwise specified, data are shown as the mean \pm S.D. (standard deviations) from three independent experiments.

\section{Supplementary information}

Supplementary information accompanies this paper at https://doi. org/10.1186/s12934-020-01420-2.

Additional file 1. Experimental detail (Table S1, Figure S1) and Additioanl data (Figure S2).

\section{Acknowledgements}

We also thank Chengjia Zhang and Nannan Dong from Core Facilities for Life and Environmental Sciences (State Key Laboratory of Microbial Technology, Shandong University) for assistance in microbial fermentation.

\section{Authors' contributions}

$C G, C L$ and $C M$ designed this study. WM, YZ, MC and WZ conducted the research. WM, YZ, MC, CY and PX analyzed the data. CG, CM, PX and WM wrote the manuscript. All authors read and approved the final manuscript.

\section{Funding}

This work was supported by the National Natural Science Foundation of China (31670041), the Grant of National Key R\&D Program of China (2019YFA0904900, 2019YFA0904803), Shandong Provincial Funds for Distinguished Young Scientists (JQ 201806), Natural Science Foundation of Shandong Provincial (ZR2018PC008), Key R\&D Program of Shandong Provincial (2019GSF107034, 2019GSF107039) and Qilu Young Scholar of Shandong University. The funders had no role in study design, data collection and interpretation, or the decision to submit the work for publication.

\section{Availability of data and materials}

All data generated or analyzed during this study are included in this published article and its additional file.

\section{Ethics approval and consent to participate}

Not applicable.

\section{Consent for publication}

Not applicable.

\section{Competing interests}

The authors declare that they have no competing interests.

\begin{abstract}
Author details
${ }^{1}$ State Key Laboratory of Microbial Technology, Shandong University, Qingdao 266237, People's Republic of China. ${ }^{2}$ Center for Gene and Immunotherapy, The Second Hospital of Shandong University, Jinan 250033, People's Republic of China. ${ }^{3}$ State Key Laboratory of Microbial Metabolism, Joint International Research Laboratory of Metabolic \& Developmental Sciences, and School of Life Sciences \& Biotechnology, Shanghai Jiao Tong University, Shanghai 200240, People's Republic of China.
\end{abstract}

Received: 5 May 2020 Accepted: 5 August 2020

Published online: 10 August 2020

\section{References}

1. Carvalho F, Prazeres AR, Rivas J. Cheese whey wastewater: characterization and treatment. Sci Total Environ. 2013;445-6:385-96.

2. Domingos JMB, Martinez GA, Scoma A, Fraraccio S, Kerckhof FM, Boon N, Reis MAM, Fava F, Bertin L. Effect of operational parameters in the continuous anaerobic fermentation of cheese whey on titers, yields, productivities, and microbial community structures. ACS Sustain Chem Eng. 2017;5:1400-7.
3. Macwan SR, Dabhi BK, Parmar SC, Aparnathi KD. Whey and its utilization. Int J Curr Microbiol Appl Sci. 2016;5:134-55.

4. Prazeres AR, Carvalho F, Rivas J. Cheese whey management: a review. J Environ Manag. 2012;110:48-68.

5. Asunis F, De Gioannis G, Isipato M, Muntoni A, Polettini A, Pomi R, Rossi A, Spiga D. Control of fermentation duration and $\mathrm{pH}$ to orient biochemicals and biofuels production from cheese whey. Bioresour Technol. 2019;289:121722.

6. Ma C, Wang A, Qin J, Li L, Ai X, Jiang T, Tang H, Xu P. Enhanced 2,3-butanediol production by Klebsiella pneumoniae SDM. Appl Microbiol Biotechnol. 2009;82:49-57.

7. Cho S, Kim T, Woo HM, Lee J, Kim Y, Um Y. Enhanced 2,3-butanediol production by optimizing fermentation conditions and engineering Klebsiella oxytoca M1 through overexpression of acetoin reductase. PLOS ONE. 2015;10:e0138109.

8. Jantama K, Polyiam P, Khunnonkwao P, Chan S, Sangproo M, Khor K Jantama SS, Kanchanatawee S. Efficient reduction of the formation of by-products and improvement of production yield of 2,3-butanediol by a combined deletion of alcohol dehydrogenase, acetate kinasephosphotransacetylase, and lactate dehydrogenase genes in metabolically engineered Klebsiella oxytoca in mineral salts medium. Metab Eng. 2015;30:16-26.

9. Ge Y, Li K, Li L, Gao C, Zhang L, Ma C, Xu P. Contracted but effective: production of enantiopure 2,3-butanediol by thermophilic and GRAS Bacillus licheniformis. Green Chem. 2016;18:4693-703.

10. Haider J, Harvianto GR, Qyyum MA, Lee M. Cost- and energy-efficient butanol-based extraction-assisted distillation designs for purification of 2,3-butanediol for use as a drop-in fuel. ACS Sustain Chem Eng. 2018;6:14901-10.

11. Cheng KK, Liu Q, Zhang JA, Li JP, Xu JM, Wang GH. Improved 2,3-butanediol production from corncob acid hydrolysate by fed-batch fermentation using Klebsiella oxytoca. Process Biochem. 2010;45:613-6.

12. Wang A, Xu Y, Ma C, Gao C, Li L, Wang Y, Tao F, Xu P. Efficient 2,3-butanediol production from cassava powder by a crop-biomass-utilizer, Enterobacter cloacae subsp. dissolvens SDM. PLoS ONE. 2012;7:e40442.

13. Li L, Li K, Wang Y, Chen C, Xu Y, Zhang L, Han B, Gao C, Tao F, Ma C, Xu P. Metabolic engineering of Enterobacter cloacae for high-yield production of enantiopure $(2 R, 3 R)$-2,3-butanediol from lignocellulose-derived sugars. Metab Eng. 2015;28:19-27.

14. Feng J, Gu Y, Yan PF, Song C, Wang Y. Recruiting energy-conserving sucrose utilization pathways for enhanced 2,3-butanediol production in Bacillus subtilis. ACS Sustain Chem Eng. 2017;5:11221-5.

15. Moon SK, Kim DK, Park JM, Min J, Song H. Development of a semicontinuous two-stage simultaneous saccharification and fermentation process for enhanced 2,3-butanediol production by Klebsiella oxytoca. Lett Appl Microbiol. 2018;66:300-5.

16. Song CW, Park JM, Chung SC, Lee SY, Song H. Microbial production of 2,3-butanediol for industrial applications. J Ind Microbiol Biotechnol. 2019;46:1583-601.

17. Saratale GD, Jung MY, Oh MK. Reutilization of green liquor chemicals for pretreatment of whole rice waste biomass and its application to 2,3-butanediol production. Bioresour Technol. 2016;205:90-6.

18. Um J, Kim DG, Jung MY, Saratale GD, Oh MK. Metabolic engineering of Enterobacter aerogenes for 2,3-butanediol production from sugarcane bagasse hydrolysate. Bioresour Technol. 2017;245:1567-74.

19. Saratale RG, Shin HS, Ghodake GS, Kumar G, Oh MK, Saratale GD. Combined effect of inorganic salts with calcium peroxide pretreatment for kenaf core biomass and their utilization for 2,3-butanediol production. Bioresour Technol. 2018;258:26-32.

20. Song CW, Rathnasingh C, Park JM, Lee J, Song H. Isolation and evaluation of Bacillus strains for industrial production of 2,3-butanediol. J Microbiol Biotechnol. 2018;28:409-17.

21. Guo XW, Zhang YH, Cao CH, Shen T, Wu MY, Chen YF, Zhang CY, Xiao DG. Enhanced production of 2,3-butanediol by overexpressing acetolactate synthase and acetoin reductase in Klebsiella pneumoniae. Biotechnol Appl Biochem. 2014;61:707-15.

22. Speckman RA, Collins EB. Microbial production of 2,3-butylene glycol from cheese whey. Appl Environ Microbiol. 1982;43:1216-8.

23. Barrett EL, Collins EB, Hall BJ, Matoi SH. Production of 2,3-butylene glycol from whey by Klebsiella pneumoniae and Enterobacter aerogenes. J Dairy Sci. 1983;66:2507-14. 
24. Champluvier B, Decallonne J, Rouxhet PG. Influence of sugar source (lactose, glucose, galactose) on 2,3-butanediol production by Klebsiella oxytoca NRRL-B199. Arch Microbiol. 1989;152:411-4.

25. Champluvier B, Francart B, Rouxhet PG. Co-immobilization by adhesion of $\beta$-galactosidase in nonviable cells of Kluyveromyces lactis with Klebsiella oxytoca: conversion of lactose into 2,3-butanediol. Biotechnol Bioeng. 1989;34:844-53

26. Xu Y, Chu H, Gao C, Tao F, Zhou Z, Li K, Li L, Ma C, Xu P. Systematic metabolic engineering of Escherichia coli for high-yield production of fue bio-chemical 2,3-butanediol. Metab Eng. 2014;23:22-33.

27. Xin B, Tao F, Wang Y, Liu H, Ma C, Xu P. Coordination of metabolic pathways: enhanced carbon conservation in 1,3-propanediol production by coupling with optically pure lactate biosynthesis. Metab Eng. 2017;41:102-14

28. Heyman B, Tulke H, Putri SP, Fukusaki E, Büchs J. Online monitoring of the respiratory quotient reveals metabolic phases during microaerobic 2,3-butanediol production with Bacillus licheniformis. Eng Life Sci. 2020;20:133-44.

29. Rebecchi S, Pinelli D, Zanaroli G, Fava F, Frascari D. Effect of oxygen mass transfer rate on the production of 2,3-butanediol from glucose and agro-industrial byproducts by Bacillus licheniformis ATCC9789. Biotechnol Biofuels. 2018;11:145.

30. Vishwakarma S. Bioconversion of whey to 2,3-butanediol using Klebsiella oxytoca NRRL-13-199. Indian J Biotechnol. 2014;13:236-40.

31. Ramachandran KB, Hashim MA, Fernandez AA. Kinetic study of 2,3-butanediol production by Klebsiella oxytoca. J Ferment Bioeng. 1990;70:235-40.

32. Kandasamy V, Liu J, Dantoft SH, Solem C, Jensen PR. Synthesis of (3R)-acetoin and 2,3-butanediol isomers by metabolically engineered Lactococcus lactis. Sci Rep. 2016;6:36769.

33. Farahnak F, Seki T, Ryu DD, Ogrydziak D. Construction of lactose-assimilating and high-ethanol-producing yeasts by protoplast fusion. Appl Environ Microbiol. 1986;51:362-7.

34. Qureshi N, Friedl A, Maddox IS. Butanol production from concentrated lactose/whey permeate: use of pervaporation membrane to recover and concentrate product. Appl Microbiol Biotechnol. 2014;98:9859-67.
35. Roukas T, Kotzekidou P. Lactic acid production from deproteinized whey by mixed cultures of free and coimmobilized Lactobacillus casei and Lactococcus lactis cells using fedbatch culture. Enzyme Microb Technol. 1998;22:199-204.

36. Arslan NP, Aydogan MN, Taskin M. Citric acid production from partly deproteinized whey under non-sterile culture conditions using immobilized cells of lactose-positive and cold-adapted Yarrowia lipolytica B9. J Biotechnol. 2016;231:32-9.

37. Ahn WS, Park SJ, Lee SY. Production of poly(3-hydroxybutyrate) from whey by cell recycle fed-batch culture of recombinant Escherichia coli. Biotechnol Lett. 2001;23:235-40.

38. Mukhopadhyay R, Chatterjee S, Chatterjee BP, Banerjee PC, Guha AK. Production of gluconic acid from whey by free and immobilized Aspergillus niger. Int Dairy J. 2005;15:299-303.

39. Jang JW, Jung HM, Im DK, Jung MY, Oh MK. Pathway engineering of Enterobacter aerogenes to improve acetoin production by reducing byproducts formation. Enzyme Microb Technol. 2017;106:114-8.

40. Zhang Y, Guo S, Wang Y, Liang X, Xu P, Gao C, Ma C. Production of D-xylonate from corn cob hydrolysate by a metabolically engineered Escherichia coli strain. ACS Sustain Chem Eng. 2019;7:2160-8.

41. Sambrook J, Russell DW. Molecular cloning: a laboratory manual. 3rd ed. Cold Spring Harbor Laboratory: Cold Spring Harbor; 2001.

42. Lee HK, Maddox IS. Microbial production of 2,3-butanediol from whey permeate. Biotechnol Lett. 1984;6:815-8.

43. Simon R, Priefer U, Pühler A. A broad host range mobilization system for in vivo genetic engineering: transposon mutagenesis in gram negative bacteria. Nat Biotechnol. 1983:1:784-91.

\section{Publisher's Note}

Springer Nature remains neutral with regard to jurisdictional claims in published maps and institutional affiliations.
Ready to submit your research? Choose BMC and benefit from:

- fast, convenient online submission

- thorough peer review by experienced researchers in your field

- rapid publication on acceptance

- support for research data, including large and complex data types

- gold Open Access which fosters wider collaboration and increased citations

- maximum visibility for your research: over $100 \mathrm{M}$ website views per year

At $\mathrm{BMC}$, research is always in progress.

Learn more biomedcentral.com/submissions 